\title{
トラニラストの滲出性中耳炎に対する効果
}

\author{
久松 建一・岸保 鉄也・後藤 領 \\ 荻野純・野沢出・村上 嘉彦

\section{Clinical Efficacy of Tranilast on Otitis Media with Effusion}

\author{
Ken-ichi Hisamatsu, Tetsuya Ganbo, Rei Goto, Jun Ogino, \\ Izuru Nozawa and Yoshihiko Murakami \\ (Yamanashi Medical University)
}

\begin{abstract}
The efficacy of Tranilast, an anti-allergic drug, in treating otitis media with effusion (OME) was clinically evaluated. One hundred twelve patients (173 ears) were divided into four different treatment groups : Group A was given Tranilast and local treatment (nasal suction and tubal catheterization); Group B received Tranilast, myringotomy and local treatment ; Group C only received local treatment (control for Group A) ; Group D received myringotomy and local treatment without Tranilast (control for Group B). The global improvement rating assessed as "moderately improved or better" was $61.7 \%$ in Group A, 78.6\% in Group B, $43.6 \%$ in Group C, and 35.0\% in Group D. There was a significant improvement in Group A compared to that in Group $C(p<0.01)$. In subjects with OME for a period of less than 2 months, Tranilast was very useful. In subjects with $\mathrm{OME}$ for seven months or longer, Group C showed significantly less improvement than Group A, B or D. These findings suggest that some kind of medication is required for OME management.
\end{abstract}

Key words : Tranilast, anti-allergic drug, otitis media with effusion

\section{はじめに}

參出性中耳炎は耳鼻咽喉科の日常診療において比較的 多い耳疾患の 1 つである. 幼小児と高齢者に多く認めら れ, 慢性に経過して真珠腫を発生する症例や癒着性中耳 炎に移行する症例もある. 小児では成長に伴い上気道の 解剖学的, 免疫学的防御機構の完成によって治癒するこ とが多いが, 難聴の改善と後遗症の発生の防止のために も治療が必要である. 鼓膜穿刺ないし切開による渗出液 の排除は中耳の陰圧状態を改善し, 聴力の改善と癒着性 中耳炎や真珠腫性中耳炎への移行を阻止するのに効果的 な基本的な処置である. しかし, その効果は一時的なこ とも多く, 滲出液の再貯留も少なくない。

換気チューブの装着は長期間中耳を陰圧から開放して
聴カレベルの低下を改善する最も確実で有効な方法であ るが, 感染, tube 周囲の肉芽の発生, 鼓膜穿孔, 真珠 腫の発生などの問題もある.また幼小児に対しては外来 での施行の困難な場合が少なくない, 従って, 參性中 耳炎の病態の解明と薬物療法の確立が望まれている. 今 回, 我々は肥満細胞からヒスタミン, ロイコトリエンや 血小板活性化因子 $(\mathrm{PAF})$ などのアレルギーの化学伝達 物質の遊離を抑制する抗アレルギー薬の 1 つである Tranilast の滲出性中耳炎に対する臨床効果の検討を行 ったのでその結果を報告する. 


\section{研究方法}

1. 対 象

山梨医科大学医学部付属病院, 石和町立峡東病院, 加 納岩総合病院, 飯富病院の耳鼻咽喉科を受診した滲出性 中耳炎患者を対象とし，本人，または家族より同意を得 た。

參出性中耳炎の診断は，患者自身の自覚症状，鼓膜所 見，聴力検査执よびチンパノメトリーなどによる他覚的 所見から総合的に行った.

急性中耳炎の先行した場合は，発症後 1 力月以上を経 たものを対象とし， 1 週間の導入期間を設けた。

\section{2 . 試験薬剂の投与方法と投与期間}

成人の場合，リザベン 1 回 1 カプセル 1 日 3 回経口投 与(Tranilastとして $300 \mathrm{mg} /$ 日) した。 小児の場合，リ ザベン細粒 $0.05 \mathrm{mg} / \mathrm{kg}$ (Tranilastとして $5 \mathrm{mg} / \mathrm{kg}$ ) を 1 日 3 回に分けて経口投与した.

薬剂の投与は， 6 週間以上の連続投与とし，この間に 薬剤の効果判定に影響を及ぼす可能性のある抗アレル ギー薬や抗ヒスタミン剤などの他の薬剤の投与を禁止し た.

\section{3. 投与方法}

參出性中耳炎患者の次の 4 群に分けて観察した.

A 群 : Tranilast 投与群

$\mathrm{B}$ 群：鼓膜穿刺または切開による滲出液除去後， Tranilast 投与群

C 群 : Tranilast 非投与群(A 群の対照).

$\mathrm{D}$ 群：鼓膜穿刺または切開による滲出液除去後, Tranilast 非投与群 (B群の対照).

外来処置として耳管処置, ネビュライザー療法を施行 した。ただし，検査前は処置を禁じた。

\section{4. 観察項目と効果判定}

観察項目は他覚的所見として, (1) 鼓膜所見の観察, (2) 標準純音聴力検査，(3)チンパノメトリーを試験開始括 よび試験終了時に施行した．効果判定は，表 1 に示す各 観察項目ごとの改善判定基準にもとついた。また，総合 評価は，表 2 に示す全般改善度判定基準にもとついた。

表 1 判定基準

I . 鼓膜所見の改善

著明改善: 陥凹及び色調のいずれも消失

$$
\mathrm{H} \rightarrow-\quad+\rightarrow-\quad+\rightarrow-
$$

中等度改善 : 陥凹又は色調の一方のみ 2 段階の改善 $\mathrm{H \rightarrow}-\mathrm{H \rightarrow} \rightarrow$

軽 度 改 善 : 陥凹又は色調の一方のみ 1 段階の改善 $\mathrm{H} \rightarrow \mathrm{H} \quad \mathrm{H} \rightarrow++\quad \rightarrow-$

不＼cjkstart変 : 陥凹及び色調のいずれも不変 $\mathrm{H} \rightarrow \mathrm{H} \quad \mathrm{H} \rightarrow \mathrm{H} \quad+\rightarrow+$

悪 化 : 陥凹及び色調のいずれも悪化 $\rightarrow+, H, H+W \rightarrow H, H \quad H \rightarrow H$ 陥凹と色調の改善度が異なる場合は良い方の改善度を採用

II. オーディオグラムの改善

$500 \mathrm{~Hz}, 1 \mathrm{kHz}, 2 \mathrm{kHz}$ の気導 4 分法

著明改善: $25 \mathrm{~dB}$ 以上の改善

改善 : $15 \mathrm{~dB}$ 以上 $25 \mathrm{~dB}$ 未満の改善

不変・悪化 : $15 \mathrm{~dB}$ 末満の改善, 悪化

III. チンパノグラムの改善

著明改善: B type $\rightarrow$ A type

中等度改善 : $\mathrm{C}$ type $\rightarrow \mathrm{A}$ type $\mathrm{B}$ type $\rightarrow \mathrm{C}$ type

軽度改善: compliance または peak圧值のみの改善

不 $\quad$ 変 $:$ B type $\rightarrow$ B type $\quad \mathrm{C}$ type $\rightarrow C$ type A type $\rightarrow$ A type

悪 化 : A type $\rightarrow C$ type, B type C type $\rightarrow$ B type

表 2 全般改善度判定基準

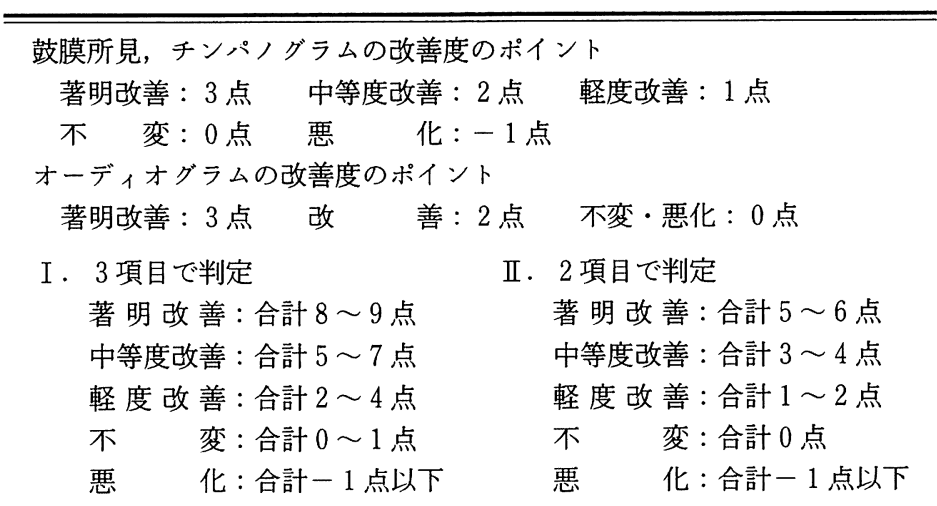


各群間の統計学的検討は, DUNN の多重比較検定を 行った.

\section{結 果}

1. 対 象

対象症例は112例，163耳であった。112例中，両側罹 患例は，61例(54.5\%)，片側罹患例は51例 (45.5\%)であ った．性別では，男性52例 (46.4\%)，女性60例 (53.6\%) であった。また，年齢別では，15歳以下が89例(79.5\%)， 50 歳以上が22例 (19.6\%)であった。各群の性別执よび年 齢別分布を表 3 に示す．合併症として副鼻腔炎を有する 者は，24例(21.4\%)であり，各群に有意差はなく，アレ ルギー素因者 (合併症または既往歷としてのアレルギー 疾患を有したり，家族歴のある者)は 5 例 (4.5\%) ときわ めて少数であった.

\section{2 . 観察日数之副作用}

Tranilast 平均投与観察日数は，A群53.7日， B 群 56.8 日, 観察日数はC 群72.8日， D群46.4日であった。 最長投与日数は $\mathrm{A}$ 群112日 (16週)，B群126日 (18週)，C 群182日(26週)，D群112日(16週)であった。しかしなが ら，これらの試験期間を通じて Tranilastによると思わ れる副作用は 1 例も見られなかった.

鼓膜穿刺または切開による滲出液除去後の鼓膜の小穿 孔は全例， 1 週間以内に閉鎖していた.

3 . 聴力改善効果

聴力改善の評価基準は $15 \mathrm{~dB}$ 以上の聴カレベルの改
善を改善, $25 \mathrm{~dB}$ 以上の改善を著明改善とした，44耳が この検討の対象になり得た. Tranilast 投与のみのA群 では改善以上の改善は $47.1 \%, \mathrm{~A}$ 群の対照の C群では $30.0 \%$ が改善以上の聴力改善を示し両群間に有意差は認 められなかった．B群では $53.8 \% ， \mathrm{D}$ 群では25.0\%が聴 力改善を示したが，有意差は認められなかった(表 4 ).

表 4 オーディオグラム (15 dB 以上)

\begin{tabular}{|c|c|c|c|c|c|}
\hline & 耳 数 & 著明改善 & 改 善 & 不 変 & $\begin{array}{l}\text { 改善以上 } \\
\text { 改善率 } \%\end{array}$ \\
\hline A & 17 & 4 & 4 & 9 & 47.1 \\
\hline B & 13 & 2 & 5 & 6 & 53.8 \\
\hline $\mathrm{C}$ & 10 & 2 & 1 & 7 & 30.0 \\
\hline D & 4 & 0 & 1 & 3 & 25.0 \\
\hline
\end{tabular}

4. チンパノグラムの改善効果

106耳が検討対象となった。A群では72.5\%，C群で は44.2\%が改善以上の改善を示し両群間の有意差が認め られた $(\mathrm{p}<0.01)$. B 群では66.7\%，D群では23.1\%が チンパノグラムの改善以上の改善を示したが，有意差は 認められなかった(表 5 ).

\section{5 . 全般改善度}

鼓膜所見, 標準純音聴力検査, およびチンパノメトリー の改善度より, 表 1, 2 に示す判定基準に従ってA群か ら $\mathrm{D}$ 群までの全般改善度を求めた(表 6 )。各群の中等度

表 3 性別及び年齢分布

\begin{tabular}{|c|c|c|c|c|c|c|c|c|c|c|c|}
\hline & & \multicolumn{2}{|c|}{ A } & \multicolumn{2}{|c|}{ B } & \multicolumn{2}{|c|}{$\mathrm{C}$} & \multicolumn{2}{|c|}{$\mathrm{D}$} & \multicolumn{2}{|c|}{ 合 計 } \\
\hline & & 症例数 & 耳 数 & 症例数 & 耳 数 & 症例数 & 耳 数 & 症例数 & 耳 数 & 症例数 & 耳 数 \\
\hline \multirow{4}{*}{$\begin{array}{l}\text { 年 } \\
\text { 齢 }\end{array}$} & $0 \sim 5$ & 13 & 23 & 4 & 4 & 13 & 22 & 2 & 3 & 32 & 52 \\
\hline & $6 \sim 15$ & 22 & 32 & 15 & 16 & 14 & 26 & 6 & 6 & 57 & 80 \\
\hline & $16 \sim 49$ & 0 & 0 & 0 & 0 & 0 & 0 & 1 & 2 & 1 & 2 \\
\hline & $50 \sim$ & 4 & 5 & 7 & 8 & 4 & 7 & 7 & 9 & 22 & 29 \\
\hline \multirow{2}{*}{ 性 } & 男 & 20 & 32 & 14 & 15 & 11 & 16 & 7 & 8 & 52 & 71 \\
\hline & 女 & 19 & 28 & 12 & 13 & 20 & 39 & 9 & 12 & 60 & 92 \\
\hline & & 39 & 60 & 26 & 28 & 31 & 55 & 16 & 20 & 112 & 163 \\
\hline \multicolumn{2}{|c|}{$\begin{array}{c}\text { 最 長 } \\
\text { 投与日数 }\end{array}$} & \multicolumn{2}{|c|}{$\begin{array}{l}\text { 112日 } \\
\text { (16週) }\end{array}$} & \multicolumn{2}{|c|}{$\begin{array}{l}\text { 126日 } \\
\text { (18週) }\end{array}$} & \multicolumn{2}{|c|}{$\begin{array}{l}\text { 182日 } \\
\text { (26週) }\end{array}$} & \multicolumn{2}{|c|}{$\begin{array}{l}\text { 112日 } \\
\text { (16週) }\end{array}$} & & \\
\hline \multicolumn{2}{|c|}{$\begin{array}{c}\text { 平 均 } \\
\text { 投与日数 }\end{array}$} & \multicolumn{2}{|c|}{53.7 日 } & \multicolumn{2}{|c|}{56.8 日 } & \multicolumn{2}{|c|}{72.8 日 } & \multicolumn{2}{|c|}{46.4 日 } & & \\
\hline
\end{tabular}


表 5 チンパノグラム

\begin{tabular}{c|c|c|c|c|c|c|c|c}
\hline \hline & 耳 数 & 著明改善 & 中等度改善 & 軽度改善 & 不 変 & 悪 化 & $\begin{array}{c}\text { 中等度以上 } \\
\text { 改善率\% }\end{array}$ & $\begin{array}{c}\text { 軽度以上 } \\
\text { 善率\% }\end{array}$ \\
\hline $\mathrm{A}$ & 40 & 13 & 16 & 1 & 10 & 0 & 72.5 & 75.0 \\
\hline $\mathrm{B}$ & 15 & 5 & 5 & 0 & 4 & 1 & 66.7 & 66.7 \\
\hline $\mathrm{C}$ & 38 & 4 & 13 & 3 & 14 & 4 & 44.7 & 52.6 \\
\hline $\mathrm{D}$ & 13 & 2 & 1 & 0 & 9 & 1 & 23.1 & 23.1 \\
\hline
\end{tabular}

表 6 全般改善度

$\left.\begin{array}{c|c|c|c|c|c|c|c}\hline \hline & \text { 耳 数 } & \text { 著明改善 } & \text { 中等度改善 } & \text { 軽度改善 } & \text { 不 変 } & \text { 悪 化 } & \begin{array}{c}\text { 中等度以上 } \\ \text { 改善率\% }\end{array} \\ \hline \mathrm{A} & 60 & 18 & 19 & 12 & 11 & 0 & 61.7 \\ \hline \mathrm{B} & 28 & 6 & 16 & 2 & 3 & 1 & 78.6 \\ \hline \mathrm{C} & 55 & 10 & 14 & 7 & 20 & 4 & 43.6 \\ \hline \mathrm{D} & 20 & 2 & 5 & 5 & 7 & 1 & 35.0 \\ *\end{array}\right]^{* *}$

以上改善率は $\mathrm{A}$ 群 $61.7 \%, \mathrm{~B}$ 群 $78.6 \%, \mathrm{C}$ 群 $43.6 \%, \mathrm{D}$ 群 $35.0 \%$ であった. 各群の軽等度以上改善率は $\mathrm{A}$ 群 81.7 $\%$ ，B群 $85.7 \%$, C群 $56.4 \%, \mathrm{D}$ 群 $60.0 \%$ であった。 各群の中等度以上改善率の比較を表 7 に示寸. 鼓膜穿 刺または切開を行っていない A 群とC 群では, Tranilast 投与群であるA 群の方が，非投与群である C 群に比較して有意な改善が認められた $(\mathrm{p}<0.01)$.また， 鼓膜穿刺または切開による渗出液除去を行っている B 群 とD群では, Tranilast 投与群である B 群の方が非投与 群である $\mathrm{D}$ 群に比較して有意な改善傾向が認められた $(\mathrm{p}<0.05)$. Tranilast 投与群の A 群と B 群の間では有意 差は認められなかった. 非投与群である C 群と D 群間で も改善率に有意差は認められなかった.

次に, A群から D群の 4 群について, それぞれの罹病 期間別に括ける軽度以上改善率の検討を行った，症例は，
罹病期間の比較的短いもの（2 カ月以内）： $\mathrm{S}$ 期と罹病期 間の長いもの（7カ月以上）：L期の 2 種類に分けた.

各群 $\mathrm{A}$ 群〜 D群における $\mathrm{S}$ 期と L 期間の有効率の検討 はA群 : $89.2 \%$ v.s. $70.0 \%$ (p<0.05), B群 : $100 \%$ v.s. $69.2 \%(\mathrm{p}<0.05), \quad$ C群 : $71.4 \%$ v.s. $27.8 \%(\mathrm{p}<0.01)$, D群 : 66.7\% v.s. $66.7 \%$ (NS) であった. すなわち，A 群〜C群において, 罹病期間の短い方が改善率が高い傾 向が見られた(表 8$)$. 罹病期間別 ( $\mathrm{S}$ 期と $\mathrm{L}$ 期)に拈ける 各群間の有効率の検討は， $\mathrm{S}$ 期に执いて， $\mathrm{A} \sim \mathrm{C}$ 群間 : $89.2 \%$ vs $71.4 \%(\mathrm{p}<0.10), \mathrm{B} \sim \mathrm{D}$ 群間 : $100 \%$ vs 66.7 $\%(\mathrm{p}<0.05), \mathrm{A} \sim \mathrm{B}$ 群間 : $89.2 \%$ vs $100 \%(\mathrm{NS}), \mathrm{C} \sim$ D群間 : $71.4 \%$ vs $66.7 \%$ (NS) であった。すなわち, 罹病期間の比較的短い症例飞沶いては, 鼓膜穿刺, 切開 の施行の有無を問わず Tranilast 投与群のほうが改善率 の高い傾向がみられた。 また，L期において，A〜C群
表 7 中程度以上改善率に拴ける各群間の比較

\begin{tabular}{c|c|c|c|c}
\hline \hline & $\mathrm{A}-\mathrm{C}$ & $\mathrm{B}-\mathrm{D}$ & $\mathrm{A}-\mathrm{B}$ & $\mathrm{C}-\mathrm{D}$ \\
\hline 有意差 & $* *$ & $*$ & $\mathrm{NS}$ & $\mathrm{NS}$ \\
& & $\begin{array}{r}* \\
\mathrm{NS}: \mathrm{p}: 0.05\end{array} \quad$ 有意差なし
\end{tabular}

表 8 各群の罹病期間別にみた有効率

\begin{tabular}{cc|c|c|c|c|c|c|c|c}
\hline \hline \multirow{2}{*}{ 羅病期間 } & \multicolumn{2}{|c|}{ A 群 } & \multicolumn{2}{c|}{ B 群 } & \multicolumn{2}{c|}{ C 群 } & \multicolumn{2}{c}{ D群 } \\
\cline { 2 - 9 } & & 耳数 & 症例数 & 耳数 & 症例数 & 耳数 & 症例数 & 耳数 & 症例数 \\
\hline $\mathrm{S}$ & 37 & $89.2 \%$ & 12 & $100 \%$ & 28 & $71.4 \%$ & 6 & $66.7 \%$ \\
\hline $\mathrm{L}$ & 期 & 20 & $70.0 \%$ & 13 & $69.2 \%$ & 18 & $27.8 \%$ & 12 & $66.7 \%$
\end{tabular}


間 : $70.0 \%$ vs $27.8 \%$ (p<0.05\%)，BＤ群間 : $69.2 \%$ vs $66.7 \%(\mathrm{NS}), \mathrm{A} \sim \mathrm{B}$ 群間 : $70.0 \%$ vs $69.2 \%(\mathrm{NS}), \mathrm{C}$ 〜 D群間 : $27.8 \%$ vs $66.7 \%(\mathrm{p}<0.05)$ であった。すな わち, 罹病期間の長い症例に打いては, 豉膜穿刺, 切開 を施行しない群では Tranilastを投与した方が改善率の 高い傾向がみられた。また，Tranilastを投与しない群 間では敨膜穿刺，切開を施行しなければ，改善率は低下 する傾向がみられた。

\section{考 察}

今回の試験に执いて対象となった患者の年齢層は， 7 〜 15 歳が $50.9 \%$ と最も多く, 次いで 5 歳以下の小児が $28.6 \% ， 50$ 歳以上のもの $19.6 \%$ といら若年層に傾きのあ る 2 峰性を示した. 中間年龄層が極端に少なかったのは, 本治験に参加した施設が，農村地区に存在しており，そ の人口構成に起因するとも考兄られるが，この疾患の患 者の 2 峰性の分布はこれまでの多くの報告と一致するも のである.

滲出性中耳炎の発症に関与する因子として，上気道炎 や急性中耳炎のような感染, アデノイド, 腫瘍, 奇形, 放射線などによる耳管の物理的, 機能的障害, アレルギー 説などが古くから挙げられている. 今回の試験の対象と なった患者には，アデノイド増殖症, 腫瘍や奇形の患者 は含まれていない，また，アレルギー素因者は 5 例(4.5 \%)と少なく, 滲出性中耳炎との関連性は認められなか った。しかしながら，若年層において滐出性中耳炎と診 断される以前に上気道炎や急性中耳炎との関連のあった 症例が大半をしめていた.レントゲン検査で副鼻腔炎と 診断されたものは，21.4\%で，経過観察中に渗出性中耳 炎が軽快したものは, 鼻腔所見も改善してゆく傾向がみ られた．これらの結果は渗出性中耳炎と感染との関連性 を示唆している.

試験を開始するにあたって，滲出性中耳炎の確定診断 には，患者自身の自覚症状のみならず，鼓膜所見，聴力 検査およびチンパノメトリーなどによる他覚的所見をそ ろえ，さらに鼓膜穿刺・切開を施行して滲出液を証明す れば完全と考兄られる。しかし，本試験に扣いては，鼓 膜穿刺・切開を施行した群 (外科的処置群) とそれを行わ なかった群(保存的処置群)の 2 群に分けなければならな かったので，參出夜の証明は括こなわず，鼓膜所見，聴 力検査扣よびチンパノメトリーなどによる他覚的所見よ り渗出性中耳炎と診断した。また，全般改善度を判定す
るにあたって幼児の場合，聴力検査を受けるだけの能力 のない者は鼓膜所見とチンパノメトリーのみで効果判定 を行った．さらに，やむをえない事情によって鼓膜所見 のみで診断されたものに対しては，鼓膜所見の改善度に 比して1ランクずつ降格するというより厳しい判定基準 を設けた(表 2 )。

試験期間中の薬物投与に関しては, 滲出性中耳炎の診 断時点では原則的に抗生物質の投与は行わなかった．し かし，鼓膜穿刺・切開を施行した患者や，急性上気道炎 に罹患した患者には 3 日間のセフェム系抗生物質の投与 が行われた．また，急性中耳炎から移行した症例に関し ては, 最低 $1 \sim 2$ 週間の抗生物質の投与が參出性中耳炎 と診断される以前に投与されて扣り，鎮痛消炎剤や消炎 酵素剂も各症例に応じて投与されていたが，発症より 1 カ月経過したものを対象としており，さらに，試験開始 以前に 1 週間の薬剂投与禁止を行っているので本試験へ の影響は少ないと考えられる.

參出性中耳炎と感染との関連が指摘される様になった のは, 中耳貯留液から Hemophilus influenzae, Streptococcus pneumoniae などの細菌が比較的高率に検出されるか らである. しかしながら，細菌培養を行らと，その数分 の 1 が培養可能にすぎない1)。この様なことからグラム 陰性菌由来の不活化菌体成分あるいはエンドトキシンが 滲出性中耳炎の発症に関与している可能性が推測されて いる. 事実，中耳粘膜や中耳貯溜液中にエンドトキシン が検出され2) 4), Hemophilus influenzae 死菌5)やエンド トキシン6), lipid $\mathrm{A}^{7)}$ の中耳への注入によって実験的中 耳炎の発症が観察されている。 また，滲出液中に免疫複 合体も検出され8), 免疫複合体の中耳への注入による実 験的中耳炎も観察されている9110). Bernstein ら ${ }^{2)}$ は滲出 性中耳炎の中耳貯留液中に活性化補体の存在を明らかに しIII型アレルギーの関与を示唆した11)。これらの実験的 渗出性中耳炎の成立過程に执いて好中球やマクロファー ジなどの炎症細胞の浸潤が指摘されており，これら細胞 が産生遊離するロイコトリェン12)やプロスタグランデ ン13)，血小板活性化因子 $(\mathrm{PAF})^{14)}$ などの各種の生物活性 物質も検出され渗出性中耳炎の発症, 遷延化汇関与して いることが推測される.

耳管粘膜上皮の $80 \%$ 以上は繊毛細胞からなり，鼻副鼻 腔と同様に広義の上気道と考えられる.耳管鼓室口より 中耳腔, 乳突洞にいたる末梢では緎毛細胞は減少する. 耳管豉室口から鼻腔にいたる耳管の障害では, 中耳腔全 
体の病変に影響を及ぼすと考えられる.

本庄15)によれば，耳管の機能は；(1) 口蓋帆張筋や口 蓋帆挙筋などの與下による動的機能と (2) 耳管の粘液繊 毛輸送機構による静的機能に分けて考えられている. 前 者はアデノイド，腫瘍，奇形などにより物理的機械的障 害を受ける. 後者の障害は感染を trigger として生じる 各種の生物活性物質によって障害を受けると考えられる. 筆者らによって炎症細胞より遊離されるロイコトリエン, プロスタグランジンやPAFなどの炎症やアレルギーの 化学伝達物質が粘液繊毛輸送機構に重大な影響を及ぼす 事が示唆されている(16) 20). また，これらの伝達物質は 血管の拡張作用や透過性の亢進, 腺分泌の妄進作用を有 するものが多い，さらに，炎症細胞の走化作用を有する 化学伝達物質もあり, 炎症の場となる耳管中耳粘膜の複 雑な炎症反応過程をへて參出液が生成されると考光られ る.しかしながら, 現在, これまでの研究成果を基礎に した薬物療法が確立されているとはいい難い状況にある。 今回，かかる観点より Tranilast の參出性中耳炎に対す る臨床効果の検討を試みた. Tranilastはアレルギー性

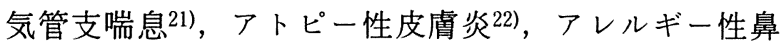
炎 ${ }^{23)}$ ，花粉症 ${ }^{24)}$ などのアレルギー性疾患の治療に有効な 経ロ抗アレルギー薬て, 現在臨床で広く用いられている 薬剤である。

Tranilast はヒスタミン25)やロイコトリエン26), $\mathrm{PAF}^{27)}$ などの化学伝達物質に対して特異的な拮抗作用を示さず に，抗原やA23187 の刺激によって種々の細胞や組織か らこれらの化学伝達物質の遊離を抑制する. 最近, Tranilast のヒト好中球よりの活性酸素の産生抑制作 用28), マクロファージやTリンパ球からのインターロ

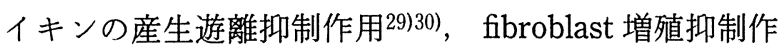
用29)などからアレルギーのみならず全般的な炎症反応 抑制効果が推測されている.

今回の試験の成績は，Tranilast が參出性中耳炎に有 効であり，これは単独投与に拈いても，また，外科的処 置による滲出液の排除後に投与した場合にも有用である ことを示した。

判定基準が異なることや今回の試験の様に群間比較が 行われていないなどの理由で正確な比較は困難であるが， 水野ら ${ }^{31)}$ は204例，366耳を対象に検討して， Tranilast の常用量を $4 \sim 8$ 週間投与して有用以上の有用度は 37.3 \%であったと報告している. 8 週間後の聴力検査で 10 $\mathrm{dB}$ 以上の聴力改善を $53.5 \%$ に認めている.また，佐々
木ら ${ }^{32)}$ は參出性中耳炎の 5 歳以下の小児49例，96耳を 対象に Tranilastを投与して有効以上 $36.7 \%$ 全般改善 度を, 8 週間後の聴力検査で $10 \mathrm{~dB}$ 以上の聴力改善を $53.1 \%$ に認め，Tranilast の參出性中耳炎に対する有効 性を報告している.

今回の検討では聴力改善の評価基準は $15 \mathrm{~dB}$ 以上の 聴力レベルの改善を改善, $25 \mathrm{~dB}$ 以上の改善を著明改善 とした. Tranilast 投与のみでは改善以上の改善は 47.1 $\%$, 対照群では $30.0 \%$ が改善以上の聴力改善を示し両群 間に有意差が認められなかった。今後症例を増して検討 すべき課題であろう。また，出性中耳炎の治療開始ま での罹病期間と治療効果の検討では，2 力月以内の急性 期括よび亜急性期 ( $\mathrm{S}$ 期)の患者群では $\mathrm{A}$ 群がC 群より改 善率の高い傾向が認められた $(\mathrm{p}<0.10)$. また，B群が $\mathrm{D}$ 群より有意に高い改善率を示した $(\mathrm{p}<0.05) .7$ 力月 以上の慢性期 ( L 期) では $A$ 群が C 群より有意に高い改善 率を示した $(\mathrm{p}<0.05)$. また，C群が $\mathrm{D}$ 群より有意に高 い改善率を示した $(\mathrm{p}<0.05)$. 寸なわち， D群が C 群よ り低い改善率を示し，慢性期の參出性中耳炎に対しては 外科的処置のみでは不充分であることを示し，薬物療法 の必要性が示唆された.

今後, 出性中耳炎の発症機序の解明への一層の努力 と新しい薬物療法の開発が極めて重要な課題であろら.

$$
\text { まとめ }
$$

化学伝達物質の産生遊離抑制作用のある抗アレルギー 剂 Tranilast を參出性中耳炎患者に投与して，外科的処 置群と保存的処置群のいずれにおいても改善率は高くな り，とくに，罹病期間の短い症例にその傾向がみられた。 また，罹病期間の長い症例に関しては，外科的処置群に 扣いては Tranilast の投与の有無では改善率に差が見ら れなかったが，保存的処置群ではTranilastを投与しな かったC群が最も低い改善率を示した.

この事は，滲出性中耳炎の治癒機転に打ける滲出液の 除去と化学伝達物質産生遊離抑制投与の重要性を示する のと思われる.

\section{参考文献}

1 ) Senturia BH, Gessert CF, Carr CD, et al : Studies concerned with tubotympanitis. Ann Otol Rhinol Laryngol 67 : 440 467, 1958 .

2 ) Bernstein JM, Praino MD and Neter E : Detection of en- 
dotoxin in ear specimens from patients with chronic otitis media by means of the limulus amebocyte lysate test. Can J Microbiol $26: 645 \sim 648,1980$.

3 ) DeMaria TF, Prior RB, Briggs BR, et al : Endotoxin in midle-ear effusion from patients with chronic otitis media with effusion. J Clin Microbiol $20: 15 \sim 17,1984$.

4 ) Jinnin T, Dake Y, Kusumoto T, et al : Quantitative determination of bacterial endotoxin in middle ear effusions by chromogenic substrate method. Auris Nasus Larynx (Tokyo) 12 : suppl $1 ; 97 \sim 99,1985$.

5 ) DeMaria TF, Briggs BR, Lim DJ, et al : Experimental otitis media with effusion following middle ear inoculation of nonviable $H$ influenzae. Ann Otol Rhinol Laryngol $93: 52 \sim 56,1984$.

6 ) Nonomura N, Nakano Y, Sato Y, et al : Otitis media with effusion following inoculation of Haemophilus influenzae type b endotoxin. Arch Otorhinolaryngol $243: 31 \sim 35$, 1986.

7) Tanimura F, Tachibana M, Morioka H, et al : Experimental otitis media with effusion induced by intratympanic lipid A instillation. Am J Otolaryngol $8: 23 \sim 30,1987$.

8 ) Palva $T$, Lehtinen $T$ and Rinne $J$ : Immune complexes in middle ear fluid in chronic secretory otitis media. Ann Otol Rhinol Laryngol 92 : 42 44, 1983.

9) Mravec J, Lewice DW and Lim DJ : Experimental otitis media ; immune-complex mediated response. Otolaryngol $86: 258 \sim 268,1978$.

10) Suzuki M, Kawauchi $H$ and Mogi G : Immune-mediated otitis media with effeusion. Am J Otolaryngolol $9: 199 \sim$ 209, 1988.

11) Bernstein JM : Biological mediators of inflammation in middle ear effusion. Ann Otol Rhinol Laryngol 85 Supple $25: 90 \sim 96,1976$.

12) Jung TTK and Juhn SK : Prostaglandins and other arachidonic acid metabolites in the middle ear fluids. Auris Nasus Larynx (Tokyo) 12 : Suppl 1 ; 148 150, 1985.

13) Jackson RT, Waitzman MB, Pickford L, et al : Prostaglandins in human ear effusions. Prostaglandins $10: 365 \sim 369$, 1975.

14) Furukawa $M$, Kubo N, Yamasita $T$, et al : Identification of plateletactivating factor (PAF) in middle ear fluids with OME. Ear Res Jpn $19: 320 \sim 321,1988$.

15）本庄 簏: 耳管と中耳病態. 13 26頁, 京都大学耳鼻咽喉 科学教室, 京都, 1987.

16）久松建一, 岸保哲也, 村上嘉彦, 他 : 鼻アレルギーに扣け る鼻粘膜非特異的過敏性発現機序に関する一考察. 耳鼻咽 喉科アレルギー危疫 $6: 55 \sim 64,1988$.

17) Ganbo $T$ and Hisamatsu $K$ : Mucosal dysfunction and damage induced by platelet activating factor (PAF). Acta Otolaryngol (Stockh) 110:427 438, 1990.

18) Hisamatsu $K$, Ganbo T, Nakazawa $T$, et al : Platelet ac- tivating factor induced respiratory mucosal damage. Lipids 26 : 1287 1291, 1991.

19) Ganbo T, Hisamatsu $K$, Nakazawa $T$, et al : Platelet activating factor (PAF) effects on human paranasal sinus mucosa in vitro. Rhinology $29: 231 \sim 237,1991$

20）久松建一, 中澤 勉, 岸保鉄也, 他 : 生理活性物質の中耳, 耳管粘膜に対する影響について 第一報 一血小板活性化 因子 PAF のモルモット耳管粘膜に対する影響一. Ear Res Jpn $20: 367 \sim 368,1989$.

21）村山雄一, 川上保雄, 堀内淑彦, 他 : 気管支喘息に扣ける $\mathrm{N}-5$ ' の薬効評価 一多施設二重盲検法による検討一. 医学 のあゆみ $108: 252 \sim 273,1979$

22）久保木 淳, 吉田彦太郎, 笹川正二, 他 : アトピー性皮膚 炎に対する N-5’ の臨床評価 一多施設群間比較二重盲検法 による検討一. 西日皮膚 $45: 621 \sim 637,1983$.

23）奥田 稔, 石川 哮, 斉藤洋三, 他 : 通年性鼻アレルギー に対する N-5' の臨床評価 一多施設群間比較二重盲検法に よる検討一. 耳展 26 補 $3: 211 \sim 250,1983$.

24）奥田 稔, 矢島 洋, 古内一郎, 他 : スギ花粉症に対する トラニラストの季節前投与による予防効果 一多施設群間 比較二重盲検法による検討一. 耳展 30 補 $3: 219 \sim 243$, 1987.

25) Nakazawa $M$, Yoshimura $T$, Naito J, et al : Pharmacological properties of $\mathrm{N}$-(3',4'-dimethoxy-cinnamoyl) anthranilic acid (N-5'), a new anti-atopic agent (5) Influence of $\mathrm{N}-5$ ' on the histamine release from peritoneal mast cells. Folia Pharmacol Japan 74 : 483 490, 1974.

26）山村秀樹, 河野茂勝, 大幡勝也, 他 : Tranilast のアナフ ィラキシー性 Chemical Mediator 遊離抑制作用. アレルギー $36: 937 \sim 942,1987$.

27) Tsutsumi N, Hara K, Komatsu H, et al : Inhibitory effect of Tranilast on the release of histamine and on the production of leukotriene (LT) and platelet activating factor (PAF). Pharmacometrics $33: 597 \sim 597,1987$.

28）木原廣美, 永田頌史, 松浦達雄, 他: Tranilastによる好 中球 $\mathrm{O}_{2}$ - 産生の抑制 医学のあゆみ $142: 775 \sim 776,1987$.

29）柳忠道, 渡辺幹生, 福田晋平, 他: Tranilast のヒト単 核球に及ぼす抑制効果炎症 $7: 169 \sim 173,1987$.

30）森田秀樹, 堀 美佳, 宮本美智子, 他：アトピー性皮膚炎 患者に拈ける末梢血 T細胞の Interleukin 2 産生能 一トラ ニラスト投与前後の対比一. アレルギーの臨床 $11: 298$ 300, 1991.

31）水野正浩, 仙波哲雄, 野村恭也, 他 : 出性中耳炎に対寸 るリザベンの効果 一関東地区多施設 open traial の結果一. 耳展 32 補 $6: 513 \sim 522,1989$.

32) 佐々木好久, 阿部博章, 徳永英吉, 他: 出性中耳炎と卜 ラニラスト。耳展 33 補 $5: 683 \sim 691,1990$.

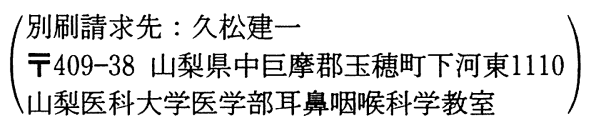

